\title{
Sociala akter som empiri. Om möjligheter och svårigheter med att använda socialarbetares dokumentation $i$ forskningssyfte
}

\section{LEILA BILLQUIST \& LISBETH JOHNSSON}

I sitt dagliga arbete dokumenterar socialarbetarna inom socialtjänsten en mängd uppgifter om sina klienter och om den hjälp som förmedlas. Dessa data borde vid sidan av intervjuer med klienter och socialarbetare vara viktiga som informationskälla när man som forskare vill studera vad som varit verksamt och vilka effekter förmedlad hjälp haft. I denna artikel diskuterar vi bland annat utifrain erfarenhet från en nyligen genomförd studie svårigheter (men också möjligheter) med aktstudier.

Inom den sociala barnavården i synnerhet, men även inom andra former av bistånd inom socialtjänsten, är det vanligt att klienter återkommer gång på gång. ${ }^{1}$ Forskning inom området visar att få klienter lämnar sitt klientskap. ${ }^{2}$ Att ett ärende avslutas är inte liktydigt med att klientskapet upphört. Antingen är familjen eller familjemedlemmen ifråga fortfarande klient vid någon

Leila Billquist, fil dr, universitetslektor, institutionen för socialt arbete, Göteborgs universitet.

Lisbeth Johnsson, professor emerita, institutionen för socialt arbete, Göteborgs universitet. annan enhet inom socialtjänsten eller så avlöses en insats omedelbart av en ny (Humlesjö 1997, Sundell 2004, Sundell et

1 Begreppet bistånd som beteckning för hjälp eller understöd infördes i Socialtjänstlagen 1980.

2 Klientskap innebär minst tre saker: att man är missgynnad, socialt eller personligt, att man på något sätt är nödlidande och att man befinner sig i en klientposition i relation till någon samhällelig instans (Bernler et al. 1989, se också Skau 1993, Salonen 1998, Billquist 1999). 
al. 2004, Billquist \& Johnsson 2004). ${ }^{3}$ Klienten kan också återkomma för förnyad insats efter ett tillfälligt avbrott i biståndstagandet (Salonen 1993, Gustafsson \& Voges 1997, Milton \& Bergström 1998, Sundell \& Egelund 2001, Bergmark 2002). Uppskattningsvis återkommer vart femte barn för ny barnavårdsutredning och insats inom ett år (Sundell \& Egelund 2001). Sundells studie (2002), som prospektivt följt en bred grupp av barnavårdsbarn över tid, visade att 41 procent av de barn som varit föremål för en barnavårdsutredning efter tre år hade återaktualiserats för minst en ny insats. ${ }^{4}$ Resultaten ligger i nivå med uppföljningsstudier gjorda i USA som också omfattat tre år (a.a.). I studien "Socialtjänstens barn. Hur många är de, vilka är insatserna, hur ofta aktualiseras de och vad händer dem i vuxen ålder?" (Sundell et al. 2004) var det 30 procent av barnen som återaktualiserats för en ny insats inom ett år och 48 procent inom tre år. Efter fem år hade andelen ökat till drygt hälften, dvs. 51 procent. Därefter återaktualiserades få barn.

3 Begreppet insats används ofta inom socialtjänsten "för att beteckna åtgärder vars syfte är att förändra eller förbättra enskilda klienters eller gruppers situation" (Lundström 2000 s. 23). I begreppet inbegrips både vad som utförs av socialtjänstens egen personal och tjänster som köps in utifrån, exempelvis kontaktperson eller kontaktfamilj (se även Regnér 2006).

4 Sundells (2002) studie är en studie av barn och unga som varit föremål för familjerådslag i Sverige. Dessa jämförs med barn och unga som varit föremål för traditionella barnavårdsutredningar som inte innefattat familjerådslag.
Ovanstående visar att behovet av att följa upp och utvärdera socialtjänstens arbete och insatser är mycket stort. Vi måste få kunskap om varför socialtjänstens arbete inte leder till att klientskap upphör liksom vad i den förmedlade hjälpen som kan vara verksamt, vad som kan bidra till att klienten kan träda ut ur sitt klientskap. Men hur skall man gå tillväga för att få sådan kunskap? Är klienten som erhåller hjälpen eller socialarbetaren som förmedlar denna den som bäst kan leverera data för att få svar på dessa frågor? Är socialarbetarens dokumentation i ärendena en möjlig källa för att få vetskap?

Inom socialtjänsten föreligger en allmän skyldighet att dokumentera som regleras av såväl förvaltnings- som socialtjänstlagen. De allmänna bestämmelserna om hur myndigheter skall handlägga ärenden finns i förvaltningslagen och i socialtjänstlagen anges hur handläggning av ärenden som rör enskilda samt genomförande av beslut om stödinsatser, vård och behandling skall dokumenteras (SFS 2001:453, 11 kap. 5§). Dokumentationsskyldigheten avser således inte enbart att utgöra en grund för beslutsfattande utan den skall även ske under verkställighet och faktiskt handlande, vilket lyfts fram redan i Socialstyrelsens allmänna råd om handläggning och dokumentation inom socialtjänsten från 1994 (1994:3). Här anges också att dokumentationen skall ha olika funktioner då den skall: »underlätta kontroll och insyn, ge underlag för uppföljning och utvärdering av olika insatser, ge underlag för forskning, ge underlag för socialnämndens och kommunens planering av inriktning och prioritering inom socialtjänstens område samt underlätta 
kontakterna inom den egna verksamheten" (a.a. s. 122).

Vanligtvis sker dokumentationen i löpande journalanteckningar, dvs. kontinuerliga och kronologiska anteckningar av betydelse för handläggning av ett ärende och genomförande av insatser. Journalanteckningarna skall föras på ett sådant sätt att den enskilde kan ta del av dem och det skall också framgå på vilket sätt den enskilde har utövat inflytande över planerade och beslutade insatser. Anteckningarna förvaras i personakten (social akt). I denna akt förvaras alla handlingar som rör den enskilde personen som är eller har varit aktuell för utredning eller insats inom socialtjänsten (Socialstyrelsen 1994:3, SOSFS 2006:5). Akterna kan i dag vara elektroniska eller fysiska eller både och.

Socialstyrelsen betonar att dokumentationen inom socialtjänsten, såväl personregister som handlingarna i personakten, skall ge underlag för forskning. Men forskare har stött på betydande problem i användningen av personakter. Framför allt har man hänvisat till informationens bristande reliabilitet, dvs. att den inte är tillförlitlig, och bristande validitet, dvs. att data sällan är relevanta för studiernas syfte och frågeställningar (se t.ex. Milton 2000). De brister som finns i aktproduktionen, menar Milton, är orsaken till att få forskare, både nationellt och internationellt, har använt sig av aktstudier i forskningssyfte eller för att utvärdera det sociala arbetets metoder och effekter.

I denna artikel diskuterar vi den sociala aktens begränsningar och möjligheter som empiriskt underlag vid studier av insatser och klientskap inom socialtjänsten.
Vi använder erfarenheter från en av oss genomförd studie inom den sociala barnavården som empiriskt exempel kompletterad med erfarenheter från annan forskning inom området. Innan vi redovisar dessa erfarenheter presenterar vi först en rad mer generella problem och begränsningar $i$ att använda och bearbeta dokumenterade data i vetenskapligt syfte.

\section{Att använda dokument - problem och begränsningar}

Användningen av dokument som källa har inte uppmärksammats i samma utsträckning som andra metoders användning inom den sociala och/eller kvalitativa forskningen, varken i den metodologiska litteraturen eller i vetenskapliga artiklar (se t.ex. Macdonald 2001, Prior 2003, MikMeyer \& Järvinen 2005). Dokument som datakälla kan inkludera en mängd olika material som exempelvis officiella dokument (protokoll, delegations- och beslutsordningar från såväl statliga myndigheter som privata organisationer), journaler och sociala akter, personliga dokument både i skriven (dagböcker, brev) och i visuell form (fotografier, filmer), tidningsartiklar och Internet. Även om dokumenten är av olika karaktär, har olika grad av tillgänglighet och varje enskilt dokument har sin specifika utformning så har de det gemensamt att de inte specifikt har tillkommit för att användas i forskning, vilket innebär begränsningar och till viss del föranleder likartade metodologiska överväganden. Här uppehåller vi oss dock huvudsakligen vid de problem och begränsningar som är förknip- 
pade med skrivet material som exempelvis sociala journaler och akter.

Ett första övervägande berör frågan om hur dokument och dess data skall betraktas. Är dokumentet en objektiv och neutral källa som ger ökad förståelse av det fenomen som undersöks? Eller betraktas dokumentet som en social konstruktion som tillkommit i ett speciellt syfte eller under speciella villkor, ett dokument som snarare ger information om ett ämne (se t.ex. Prior 2003, Mik-Meyer 2005) än »rättı förståelse av företeelsen? ${ }^{5}$ Under senare år har denna diskussion förts fram och följer därmed diskussionen som sådan inom vetenskapssamhället - att data betraktas och behandlas olika med hänseende till forskarens syn på kunskap. Det handlar, som vi ser det, också om vilken typ av dokument som används $i$ undersökningen, vilken typ av data dokumentet innehåller, vilka uppgifter som är relevanta för, och hur de används i, den specifika forskningen samt vilka anspråk forskaren har. Är det register, med sitt värde som tecknare av större och grövre bilder, eller är det t.ex. sociala akter där annan information eftersökes som utgör studiens källmaterial (se Vinnerljung 1992)? Kanske används vissa dokument eller delar av dokument enbart för att få faktiska uppgifter, s.k. basfakta, om t.ex. nationalitet, kön, ålder, civilstånd, hemort, familjebakgrund, sysselsättning, vårdtider m.m. (se t.ex. Framme 1997, Johansson et al. 2006). Andra används för mer sökande av process-

5 Prior (2003 s. 26) menar t.ex. att dokument måste betraktas som "... situated products, rather than as fixed and stable 'things' in the world». data, dvs. att se utveckling och förändring över tid (se t.ex. Bernler \& Johnsson 1993, 1995, Billquist \& Johnsson 2004).

Att problematisera frågan om dokument och dess användning har bl.a. gjorts av Scott (1990). Han tycks ha eller har haft en central betydelse då referenser till honom återkommer i de flesta metodologiska böcker som behandlar dokument som datakälla (se t.ex. Macdonald 2001, Bryman 2004, Thomas 2004), samtidigt som han nu delvis ifrågasätts för att för mycket ha fört fram en "sanningsdiskurs" (Mik-Meyer 2005 s. 194). Scott menar att dokument inte får betraktas som oproblematiska och anför följande fyra kriterier för att värdera dokument och dess data: tillförlitlighet (authenticity), trovärdighet (credibility), representativitet (representativeness) och mening/betydelse (meaning).

De olika kriterierna har olika innebörd och ger upphov till olika frågor som kan ställas till det undersökta materialet. Tillförlitlighet, med underrubrikerna soliditet och författarskap (soundness and authorship), handlar om huruvida dokumentet är ett originaldokument och t.ex. om det finns några tvivel avseende författarskapet. Är författaren den som faktiskt har skrivit dokumentet eller är det någon annan? Trovärdighet, handlar om uppriktighet och noggrannhet (sincerity and accuracy), dvs. är dokumentet fritt från fel och förvanskningar. Frågor som vem, varför, när, till eller åt vem samt i vilket sammanhang dokumentet gjordes blir centrala. Representativitet innebär bl.a. om dokumentet är typiskt för sitt slag. Om det inte är det känner man då till $i$ vilken utsträckning det är atypiskt? Det kan också handla om huruvida 
allt material är tillgängligt eller inte. T.ex. finns allt material, all dokumentation med i den sociala akten? Om något saknas, i så fall vad och hur viktigt kan det anses vara? Slutligen det fjärde kriteriet, mening, har egentligen två innebörder eller omfattar två nivåer - bokstavlig/ordagrann och tolkande förståelse (literal and interpretative understanding). Är dokumentet begripligt (går det att läsa)? Och hur ska det förstås? I det senare fallet krävs en förståelse för det sammanhang i vilket det tillkom. Kriteriernas relevans varierar med hänsyn till det slags dokument som bedöms (Bryman 2004). Kritikerna har hävdat att ett dokument och dess uppgifter måste analyseras och tolkas inte enbart i relation till den sociala kontext där det har producerats utan också i relation till den där det kommer att konsumeras (Mik-Meyer 2005, se även Prior 2003). Dokumentet får således betydelse först i det sammanhang det används, dvs. på vilket sätt, av vem, i vilket syfte och vilka konsekvenser det får i praktiken. ${ }^{6}$

\section{Att använda sociala akter - problem, begränsningar och överväganden}

Att vetenskaplig bearbetning av data, som producerats med helt andra intentioner än den vetenskapliga, stöter på betydande svårigheter har uppmärksammats i olika sammanhang (t.ex. Scott 1990, Bernler \& Johnsson 1993, Holbrook 1995, Staudt

6 Detta gäller inte endast i vetenskapliga sammanhang utan även i klinisk praktik (se t.ex. Scott 1990, Staudt 1999).
1999, Milton 2000). En rad faktorer i aktproduktionen, varav några redan kortfattat berörts, bidrar till dessa svårigheter.

Uppgifter i sociala akter/personakter är t.ex. inte insamlade i forskningssyfte utan de är snarare ett resultat av socialsekreterarens subjektiva bedömning av vad som bör dokumenteras eller som anses organisatoriskt nödvändigt för att fatta beslut (Hollander 1985, Vinnerljung et al. 2001, Staaf 2004). I många fall verkar noteringarna vara gjorda enbart för watt visa att 'man' gjort något“ (Nilsson 1989 s. 15) och det kan finnas anledning att vara försiktig $i$ förhållande till akternas informationsvärde. Ofta saknas eller ges osäker information som är värdefull för forskningen, t.ex. om klienternas bakgrund och de sociala insatsernas innehåll och genomförande (Hollander 1985, Buhr et al. 1990, Bergmark 1991, Vinnerljung 1996, Gerdner 2004). ${ }^{7}$ Nilsson (1989) framhåller i sin studie att det t.ex. saknades grundläggande och väsentlig information kring de människor akterna gällde och att det var vanligt att orsakerna till olika beslut och ställningstaganden också saknades (jfr. t.ex. Hollander 1985, Mattson 1998). Bland annat frågar sig Nilsson om journalanteckningarna säger mer om den person som gjort anteckningen än om klienten som avses. Hollander (1985 s. 77) påpekar att det förmodligen är svårt

7 Vinnerljung et al. (2001 s. 87) uppmärksammar i sin studie om sammanbrott vid tonårsplaceringar att akterna var mer "svårtolkade« då det gällde information om tidigare förhållanden och tonåringarnas uppväxt än t.ex. information om barnets konkreta livssituation och beteende, dvs. det som låg till grund för beslut. 
att fånga in socialarbetarens kännedom om familjerna i ett precist och exakt språk. Ofta blir det vaga och enkla uttryck, exempelvis missbruk, för att beskriva en klients problem. Allsidigheten och pålitligheten i presentationen av fakta kan också ifrågasättas då positiv information eller motstridiga bilder av klienten och dennes situation sällan framkommer (a.a., Bernler \& Johnsson 1993, 1995). De sociala akternas kvalitet och utförlighet är högst varierande.

Ytterligare begränsningar $i$ användandet av sociala akter och journaler i vetenskapliga sammanhang är att organisationerna (socialbyråerna)ändrar sitt arbetssätt över tid. Man ändrar sitt sätt att dokumentera vilket kan medföra svårigheter att göra jämförelser och att utläsa förändring för klienten - däremot inte förändring i ideologi och synsätt. Då olikheter också är stora i hur man dokumenterar, bl.a. beroende på bristen av gemensamma begrepp och definitioner, mellan olika socialkontor och verksamheter begränsar även det metodens användning (Hydén 1991, Vinnerljung 1992, m.fl.). Kanske lämpar den sig bäst då man arbetar med en eller två socialbyråer (se t.ex. Staudt 1999)?

Brister i dokumentationens kvalitet och avsaknad av viktig information utgör dock bara en slags problematik när aktdata skall bearbetas vetenskapligt. En helt annan problematik är den som handlar om aktens förhållande till den bakomliggande "verkligheten", framför allt klientens verklighet. Ibland har forskare haft som mål att „komma åt» denna bakomliggande verklighet så som den speglas i akten. En sådan långtgående målsättning är varken rimlig eller möjlig (se t.ex. Bernler \& Bjerkman 1990, Mik-Meyer 2005). Alla journaler är sociala konstruktio- ner skrivna av människor vars värderingar, antaganden, organisationstillhörighet, institutionella ramar, arbetsplatskultur och anställningsförhållanden påverkar vad som skall skrivas in som sociala fakta (se t.ex. Holbrook 1995, jfr. Lipsky 1980). Akterna är ett sätt att konstruera verkligheten - klientens verklighet och den verklighet $\mathrm{i}$ vilken insatsen/hjälpen förmedlas. Det är socialsekreterarens bild av situationen som återspeglas i akten (Bernler \& Johnsson 1993, 1995, Johansson et al. 2006). Klienten är ingen medförfattare utan akten är oftast ensidigt producerad av tjänstemannen och speglar därmed ett myndighetsperspektiv och en begränsad del av verkligheten (Hydén 1991, 1995, Vinnerljung 1992). Den sociala akten (journalanteckningar, utredningstexter m.m.) får ofta funktionen av en redogörelse för och, för att citera Hydén (1991 s. 7), nen legitimering av institutionens eller myndighetens agerande $i$ relation till klienten eller patienten". Den ger således ingen fullständig bild av händelserna utan den är konstruerad av och i organisationens intresse (Parton et al. 1997).

Överväganden som bör göras då sociala akter används som empiriskt material handlar inte enbart om var och hur akten har konstruerats och vems eller vilken bild den speglar utan också om hur texten "läses" - i vilket sammanhang, på vilket sätt, av vem och i vilket syfte akten och dess data skall användas, dvs. vilka anspråk forskaren har. I forskning där sociala akter (eller institutionella texter) har använts som empirisk källa kan olika användningsområden och traditioner urskiljas (Hydén 1995). Akterna kan ha använts som underlag för statistiska bearbetningar avseende exempelvis klientkarak- 
täristiska och insatser (t.ex. Vinnerljung 1996, Vinnerljung et al. 2001, Sundell et al. 2004), som underlag för uppgifter om demografiska data (t.ex. Framme 1997, Johansson et al. 2006), eller som underlag för mer konstruktivistiska eller sociolingvistiska ansatser, t.ex. vilken funktion akten fyller i en organisation, vad texten ger uttryck för eller hur diskurser aktiveras i texter (t.ex. Cedersund 1992, Hydén 1991, 1995, Friis 2003, jfr. Mik-Meyer 2005). Vinnerljung et al.(2001 s. 88) för t.ex. fram att då deras studie av sammanbrott vid tonårsplaceringar handlar om socialtjänstens insatser och om dessa har varit genomförbara så betraktar de placeringarna ur »socialtjänstens eget perspektiv«. Det är socialtjänstens motiv till placeringar av tonåringar som forskarna utgår från och i en sådan kontext är, menar de, de sociala akterna en adekvat källa för att få en översiktlig bild av vårdsystemet för tonåringar. Som tidigare nämnts måste värdet av aktdata bedömas utifrån vilken typ av uppgifter det är, relaterat till forskningsstudiens syfte och frågeställningar samt i vilket sammanhang den konsumeras (se vidare s. 13).

\section{Det empiriska exemplet}

Studiens centrala frågeställning var om klientskaps upphörande är ett resultat av ett systematiskt och målinriktat socialt arbete eller om det är helt andra faktorer som avgör. Den ursprungliga planen var att genomföra en pilotstudie omfattande en undersökning av dokumentationen i ett begränsat antal avslutade ärenden, där bistånd givits i form av råd, stöd och behandling till familjer inom den sociala barnavården. Ärendena skulle ha avslutats minst två år före det undersökningen genomfördes. Denna pilotstudie skulle sedan leda vidare till en mer omfattande dokumentationsstudie av avslutade ärenden, vilken i sin tur skulle utgöra en grund för ett urval av ärenden, i vilka genomfördes kvalitativa intervjuer med såväl socialsekreterare som klienter. Tyngdpunkten skulle ligga på klientintervjuerna (intervjuer med f.d. klienter). På grund av bristande finansiering men också på grund av de erfarenheter som gjordes då pilotstudien genomfördes kom projektet att få en delvis annan uppläggning. Tyngdpunkten kom att förskjutas från klientintervjuer till en granskning av dokumentationen i avslutade ärenden kompletterad med intervjuer med socialsekreterare. Ett mindre antal klientintervjuer genomfördes dock. Att dessa blev så få beror främst på att det fanns så få att intervjua. Av de avslutade ärendena visade sig nämligen enbart en ringa del representera ärenden där klientskap upphört. Studien var förlagd till en barn- och familjeenhet i ett område där många människor är beroende av socialtjänstens insatser. Till enheten kunde man vända sig helt frivilligt för att få råd, stöd och hjälp i t.ex. krissituationer. ${ }^{8}$

\section{Granskningen av dokumentationen}

Granskningen av dokumentationen har gjorts i ett urval av ärenden som avsluta-

8 För ytterligare information om studien och dess uppläggning se Billquist \& Johnsson (2004). 
des under år 2001. För att kunna göra detta urval var vi naturligtvis intresserade av hur många ärenden som avslutades detta år, vilket visade sig vara en svår fråga. Det fanns nämligen både en datorbaserad dokumentation och en av enhetschefen egen förd statistik. Mellan dessa fanns en diskrepans i antalet ärenden. Bl.a. visade det sig finnas fler avslutade ärenden i den av enhetschefen förda statistiken än i datalistan samtidigt som ett stort antal av datalistans ärenden saknades i den egna statistiken. Orsaken till detta lyckades vi inte reda ut. Efter att ha granskat och jämfört de båda listorna fann vi slutligen att det måste vara 206 ärenden som avslutats. Dessa utgör basen för den sortering, kategorisering och granskning som gjordes.

I underlaget till den av enhetschefen förda statistiken anges anledningen till att ett ärende avslutas. ${ }^{9}$ Denna kategorisering utgick vi från då vi sorterat ärendena i grupper. Att just fokusera anledningen till att ett ärende avslutas borde ge viktig information om vägen ut ur systemet, menade vi. Det visade sig dock inte alltid vara så klart vilken kategori ett ärende hörde till. Gränsdragningen mellan olika kategorier var i flera fall diffus. T.ex. kunde ett ärende av en socialsekreterare ha kategoriserats som "klienten avbryter kontakten" medan

9 Följande skäl angavs till ett ärendes avslut: Ansökan fullföljdes inte, Behandlingsplanen är uppfylld, Klienten avbryter kontakten, Utredning på utredningsenheten, Anmälan till utredningsenheten, Klienten har flyttat, Utredningsenheten avbryter uppdraget, Hänvisning till annan instans samt Annat. en annan socialsekreterare kunde kategorisera ett nästan identiskt ärende som att "ansökan inte fullföljdes». Vi har inte gjort någon omklassificering utan vi har troget följt den kategorisering som gjorts vad avser ärendena i enhetens egen förda statistik, även om vår läsning av dokumentationen $\mathrm{i}$ ärendet kanske mer pekat på annan avslutningskategori. I de ärenden som inte ingick i den av enheten egen förda statistiken har vi själva valt kategori utifrån en bedömning av det som dokumenterats. Vi har, av de 206 ärendena, djupare granskat 52 , vilket inneburit att vi läst all befintlig dokumentation i dessa ärenden. Det är ärenden som tillhör Familjecentrum, gruppen inom enheten som arbetar med barn upp till tolv år, och som har kategoriserats som "behandlingsplanen är uppfylld“ (20), »klienten har avbrutit kontakten" (23) och "klienten har flyttat" (9). De sist nämnda har granskats för att se i vad mån dessa ärenden är likartade de övriga eller om de skiljer sig åt.

Den information och dokumentation som granskats i de utvalda ärendena är datorbaserad. Förutom rena registreringsuppgifter finns i dokumentationssystemet (kallad dokSOTIS) personblad, journalblad, löpande anteckningar och eventuella utredningar i ärendet. I dessa olika dokumenttyper finns biståndsansökningar och beslut antecknade liksom socialsekreterarens kontakter med klienten/familjen och andra i ärendet involverade personer. I flertalet men långt ifrån alla ärenden finns också en eller flera utredningar som legat till grund för beslutet om bistånd. Ett ärendes samtliga handlingar utgör således ärendets sociala akt.

Till en början hade två undersöknings- 
instrument utarbetats för läsning och insamlande av information från de sociala akterna. Det var dels ett "familjeblad» där uppgifter skulle antecknas om familjens sammansättning, familjemedlemmarnas ålder och kön, nationalitet, yrke, sysselsättning, dvs. demografiska data. Dels var det ett ganska omfattande "frågeformulär" som gällde själva kontakten med barn- och familjeenheten. Här fanns frågor om anledningen till kontakten, vilken hjälp klienten önskade, vilka problem som initialt beskrevs, vilken bedömning som gjordes av problem och hjälpbehov m.m. På ett blankt blad skulle vi beskriva processen i ärendena. Vår avsikt var att göra ett slags synopsis utifrån de anteckningar som fördes vid besöken hos socialsekreteraren och andra kontakttillfällen och som förhoppningsvis beskrev utvecklingen i ärendet. Särskilda frågor fanns om avslutningen av ärendet.

Efter att ha prövat dessa instrument $i$ ett par ärende insåg vi att de inte fungerade. Dokumentationen i ärendena var alldeles för mager för att vi skulle kunna få svar på annat än ett litet fåtal av våra frågor. Inte ens familjebladet kunde fyllas i med någon större säkerhet då det ofta saknades uppgifter om t.ex. nationalitet, sysselsättning och ibland till och med hur familjesammansättningen såg ut. Frågeformuläret omarbetades då till att endast omfatta ett fåtal frågor. Utöver dessa antecknade vi fritt i varje ärende allt vi fick veta om a) klienten/familjen, b) om problemen, c) om själva insatsen/hjälpen (och i förekommande fall processen) samt d) om själva avslutningen av ärendet. Läsningen och granskningen av dokumenten gjordes av oss båda gemensamt, vilket varit en klar fördel då vi kunde stämma av med varandra att vi uppfattat det skrivna på ett likartat sätt.

\section{Dokumentationens kvalitet}

Att det kan finnas svårigheter och problem vid läsning av akter var vi medvetna om och vi förväntade oss också vissa brister i dokumentationen, men att den var så bristfällig som den visade sig vara hade vi inte väntat oss. För att få fram uppgifter om klienten och klientskapet var vi många gånger tvungna att läsa mer än en akt då uppgifterna kunde finnas dokumenterade i akter tillhörande andra familjemedlemmar.

I så gott som samtliga studerade ärenden var informationen knapphändig och ofullständig. Uppgifter om hur ärendet hade aktualiserats, dvs. vem som tagit initiativ till kontakten och hur klienten fått kännedom om att hon/han kunde vända sig till just Familjecentrum gick inte att utläsa mer än i drygt en tredjedel av ärendena. Av dokumentationen var det också ytterst svårt att utläsa vilka problem och hjälpbehov som föranledde kontakten med barn- och familjeenheten. Dokumentationen startade oftast med en ansökan om visst bistånd - inte med vad som lett fram till denna ansökan. Precis som vi sett i tidigare aktstudier (Bernler \& Johnsson 1995) gjordes en omformulering av klientens problem och initiala hjälpbehov till en ansökan om bistånd i någon form. Många ärenden saknade helt problembeskrivningar. I de fall sådana fanns var de mycket knapphändiga och otydliga. Det framgick inte heller alltid vad man gör i ärendena. I dokumentationen var socialsekreterarnas egna insatser prak- 
tiskt tagit osynliga. Vilken hjälp förmedlade socialsekreterarna i sina råd- och stödkontakter? Vad innehöll t.ex. parsamtalen för något? Vilket mål hade man med dessa stödformer? Och hur vet man att behandlingsplanen uppfyllts när målet för behandlingen inte finns dokumenterat? I endast få fall av de granskade ärendena fanns avslutande samtal dokumenterade. I övrigt gavs ingen information om hur det gick till när ärendet avslutades. Och vilken betydelse hjälpen haft för klienterna gick inte heller att utläsa mer än i ett fåtal ärenden där klienten förklarade sig nöjd med den hjälp som de fått. I ärenden där klienten avbrutit kontakten gavs inte någon information om orsaken till avbrottet eller funderingar kring orsaker. Det fanns inte heller någon summering eller värdering av vad som hade gjorts. Överhuvudtaget var det ytterst sällan som klientens röst hördes i dokumentationen (jfr. Shireman \& Grossnickle 1990, Holbrook 1995, Mattson 1998, Aronsson 2001).

Mycket visade sig vara diffust, allt från hur ärendet initierades till hur avslutningen skett. Otydligheten var stor både vad gällde problembeskrivning, analys och bedömning, hjälpens innehåll m.m. Vad som händer eller hände under resans gång gick inte alls att utläsa av dokumentationen då avsaknaden av processdata var så gott som total.

Att, med utgångspunkt från den aktstudie som här redovisats besvara forskningsprojektets frågeställning om hur vägen ut ur ett klientskap kan se ut går inte (och knappast inte heller med hjälp av de kompletterande intervjuer som gjorts då ett större antal krävts, framför allt fler klient- intervjuer). Om man inte får veta något om varför och hur resan påbörjades, vad resmålet är och vad som händer under resans gång, ja då blir vägen ut ur klientskapet höljd i dunkel.

Dokumentationen i detta exempel är inte bara av dålig kvalitet för att kunna utvärdera enhetens arbete, metoder och insatser samt för att få veta något om vad som händer klienterna och hur det har gått för dem. Den är också dålig som administrativt och behandlingsmässigt underlag. Den socialsekreterare som tar över ett ärende kan inte bli insatt i detta enbart genom att läsa akten. Dokumentationen kan inte heller utgöra ett instrument i behandlingsarbetet. En fylligare dokumentation behövs för att få överblick, se mönster och för att kunna göra analyser och bedömningar i enskilda ärenden (Johnsson 1999). Väl genomförd dokumentation med bedömningar och summeringar kräver att socialarbetaren tänker igenom vad hon/han gör och varför - ett svårt men nödvändigt moment $\mathrm{i}$ arbetet (Gelman 1992).

\section{Några slutsatser}

Att utifrån ett enstaka exempel uttala sig om aktforskningens möjligheter och begränsningar mer generellt är givetvis inte rimligt. Många av de problem vi stötte på har sin grund i denna speciella enhets sätt att förhålla sig till dokumentation överhuvudtaget. Dels saknades tydliga riktlinjer och rutiner för vad och hur man skulle dokumentera. Dels hyste socialsekreterarna en förhoppning, när de sökte sig till enheten, att de enbart skulle få ägna sig åt 
behandlingsarbete och slippa dokumentera (vilket ju inte var möjligt). Samtidigt visar dock vårt exempel på en rad mer generella problem, som vi känner igen från tidigare aktforskning, egen och andras.

För det första kan vi konstatera (kanske självklart?) att data inte producerats i syfte att användas i forskningssammanhang utan för att ligga till grund för beslut om bistånd och möjligen för att, i vart fall knapphändigt, redovisa vilka insatser som genomförts $i$ ärendet. Men även som beslutsunderlag var informationen bristfällig då den i många fall saknade uppgifter om t.ex. tidigare fattade beslut och vad som gjorts i ärendet. Den saknade därmed den typ av byråkratisk/administrativ information som brukar anses organisatoriskt nödvändig i socialtjänstens arbete (jfr. t.ex. Vinnerljung et al. 2001). Avsaknaden av processdata var, som tidigare nämnts och som vi sett $i$ andra sammanhang (se t.ex. Bernler \& Johnsson 1995, Linderot 2006), också så gott som total. För vårt forskningssyfte var sådana data av stor vikt.

Ett annat problem som har att göra med det sammanhang i vilket data producerats är avsaknaden av en gemensam terminologi. Vad menades t.ex. med olika avslutningskategorier? När skulle ett ärende betraktas som att behandlingsplanens mål var uppnått och när skulle ett ärende ses som att kontakten hade avbrutits? Inom enheten rådde ingen överensstämmelse om detta. Bristen på gemensamma begrepp och definitioner var stor. Detta begränsade, precis som annan forskning också visat, användningen av den sociala akten i forskningssyfte (se t.ex. Hollander 1985, Nilsson 1989, Bernler \& Bjerkman 1990, m. fl.). Bristen på en gemensam terminologi innebar inte enbart att det skulle försvåra, ja kanske helt omöjliggöra en eventuell jämförelse med andra socialbyråer och verksamheter utan det skulle även försvåra en utvärdering av enhetens eget arbete och insatser. Akten skulle inte kunna ge information om eller utgöra underlag för en förståelse av det klientarbete som bedrevs.

Inte ens enhetens administrativa data, dvs. de statistiska uppgifterna om antal avslutade ärenden under år 2001, gav helt tillförlitlig information. Om den data som förs in på olika register visar sig vara så pass osäker, som den vi tagit del av, hur kan då dessa register med dess statistiska uppgifter säga oss något om hur det går för klienterna eller om olika insatsers värde?

\section{Att använda sociala akter - fördelar och möjligheter}

Det finns som några forskare har pekat på fördelar, kanske framför allt praktiska, med att använda akter i forskningssammanhang, t.ex. att akter är lättillgängliga och att forskningen kan ske diskret och utan att kräva tid och ansträngning av socialarbetare och klienter. Vidare är risken för bortfall mindre än vid intervjuundersökningar och även en del etiska problem kan undvikas, exempelvis vid studier om barn (Vinnerljung 1996, Vinnerljung et al. 2001). Akter ger också säkrare uppgifter än intervjuer då det gäller förfluten tid då de inte som vid intervjuer påverkas av personliga minnen och de är bra att använda för retrospektiva studier (Neij 2005). En fördel är, menar t.ex. Bucht (1997), att man som forskare har en bättre 
möjlighet att följa processen i ett ärende från den dag det aktualiseras till den dag det avslutas, vilket i och för sig förutsätter att sådan data finns införda i akten. Aktstudier kan också vara ett praktiskt alternativ till "renodlat prospektiva longitudinella undersökningar" (Vinnerljung et al. 2001 s. 88). Akter har kanske sitt största värde $i$ att de kan användas för att studera organisatoriskt viktiga mönster i det sociala arbetet, t.ex. hur klienter och sociala fenomen konstrueras (se t.ex. Parton et al. 1997). De är dessutom en billig källa att använda sig av om de är välorganiserade och »up-todate» (Staudt 1999 s. 421).

Akterna i vårt exempel var dock inte "välorganiserade« vilket vi inte ser som unikt för den undersökta enhetens arbete. Frågan är då hur sociala akter kan bli mer användbara i forskningssammanhang. Kanske behövs en förändring av själva sättet att dokumentera?

I dag ställs alltmer uttalade krav på en evidensbasering av professionella insatser inom socialtjänsten och angränsande verksamheter. I samband med detta har olika metoder för systematisk dokumentation introducerats, ASI (Addiction Severity Index), BBIC (Barns Behov I Centrum) för att nämna några. ASI är tänkt att inte enbart ge stöd i det enskilda klientarbetet utan också kunna utgöra underlag för verksamhetsutveckling och användas för forskningsändamål (se t.ex. Andréasson et al. 1999). På motsvarande sätt kan man säga att BBIC, som är ett kvalitetssystem för att åstadkomma bättre utredning, planering och uppföljning där barns ställning i den sociala barnavården skall stärkas, också är tänkt att vara underlag för utvecklingsoch förändringsarbete (Johansson 2004).
Tanken är att klientens behov och situation, att socialarbetarnas överväganden och beslut tydligare skall dokumenteras. Frågan är om en sådan systematisk dokumentation skulle kunna undanröja de problem och brister som vi stötte på i vår dokumentationsstudie. Blir det lättare att göra vetenskapliga studier av det sociala arbetet och dess värde för klienterna? Får vi veta mer om hur det går för klienterna? Ger dokumentationen större "tillförlitlighet»?

Forskning inom området visar att åtminstone till vissa delar så kvarstår samma problem vid användningen av systematiska dokumentationsmetoder för både forskningsändamål och behandlingsarbete som vid användningen av andra dokumentationsformer. T.ex. visar Alexandersons (2006, 2006 b) studie att instrumenten (ASI eller IUS), åtminstone på kort sikt, inte användes på det sätt som var tänkt. ${ }^{10}$ Socialsekreterarna prioriterade inte uppföljande samtal, vilket var en del av den systematiska dokumentationen, utan snarare föreföll det viktigare att "ge hjälp än att veta något om hjälpens effekter för klienterna» (2006 b s. 37). Alexanderson menar att det finns en hel del hinder (t.ex. hög personalomsättning bland socialsekreterarna, bristande tid, juridiska hinder, brister i stöd och arbetsledning), i införandet av nya dokumentationssystem inom socialtjänsten, vilket också lyfts

10 IUS är, precis som ASI, tänkt att utgöra en modell för stöd i det enskilda klientarbetet och samtidigt ge underlag för verksamhetsutveckling (Sandell 2003 i Alexandersson 2006 s. 19). IUS har dock ett vidare användningsområde inom socialtjänsten än ASI, som enbart är tänkt att användas inom missbruksområdet (a.a.). 
fram av Engström och Armelius (2005). De menar att erfarenheter från implementeringsforskningen visar att det tar lång tid att "förändra komplexa organisationer och särskilt när förändringen utmanar den gällande kulturen« (a.a. s. 40). Risken finns således att den systematiska dokumentationen inte använts fullt ut. Dessutom är de uppgifter som samlas in alltför individbaserade (Alexanderson 2006b). Uppgifter som skulle kunna hänföras till strukturella förhållanden finns inte och dessutom finns inget om eventuella »orsaker" till klientens problem och situation varken på individnivå eller på strukturellnivå. Å andra sidan då data sammanställs på aggregerad nivå får man kunskap om det generella på bekostnad av det individuella (von Greiff 2006).

Ytterligare en tvetydighet i användningen av systematiska dokumentationsmetoder är hur "lika" socialarbetarna är $\mathrm{i}$ sina bedömningar av vad som t.ex. är sociala problem. Forskning, inte minst Skogens (2005) vinjettstudie om socialsekreterares bedömning av socialbidragstagare med begynnande alkoholproblem, visar stor spridning i bedömning och agerande bland studiens socialsekreterare. Även von Greiff (2006) pekar på i sin studie om ADAD (Adolescent Drug Abuse Diagnosis) som verktyg för bedömning och behandling av missbruk bland ungdomar på särskilda ungdomshem att det finns betydande skillnader mellan bedömningar av förekomst och omfattning av missbruk och vilka ungdomar som anses ha problem beroende på vilka uppgifter man använder. Resultaten visar att bedömningarna av både omfattning och hur »... (miss)bruket uppfattas skiljer sig åt dels med utgångspunkt i socialtjänstens placeringsorsak och ungdomarnas självrapporterade uppgifter och dels i ungdomarnas respektive intervjuarnas skattningar av missbruk, såsom de framkommer i ADAD« (a.a. s. 159). ${ }^{11}$ Skillnaderna i uppfattningar, menar von Greiff, torde höra samman med den övergripande problematiken kring vad som menas med sociala problem.

Inte minst de två sistnämnda exemplen visar på, menar vi, den problematik som gäller all användning av dokumentation som empirisk källa och som vi som forskare måste förhålla oss till, nämligen att all dokumentation är sociala konstruktioner gjorda av människor vars värderingar, tankar, antaganden, organisationstillhörighet m.m. påverkar vad som dokumenteras som s.k. sociala fakta. Således kvarstår samma problematik vid användandet av den systematiska dokumentationen som den typ av dokumentation vi använt i vår studie.

En väl förd dokumentation kan ge många värdefulla uppgifter för forskningen, både vad avser uppgifter av fakta- och av processkaraktär. Men man måste alltid ha i åtanke att akten är konstruerad i ett visst avseende och sammanhang och dess användbarhet $i$ forskningshänseende styrs av den fråga som vi vill veta något om. Med en sådan medvetenhet kan akten utgöra en möjlig källa i studier av insatser och klientskap inom socialtjänsten.

11 Intervjuarna är den institutionspersonal som genomför ADAD-intervjun (von Greiff 2006). 


\section{Referenser}

Alexanderson, K. (2006) Vilja Kunna Förstå om implementering av systematisk dokumentation för verksamhetsutveckling $i$ socialtjänsten. Örebro studies in Social Work 7. Örebro: Örebro universitet, Institutionen för beteende-, social- och rättsvetenskap.

Alexanderson, K. (2006 b) "Systematiska bedömningsinstrument i teori och praktik». Socionomen, nr 4, s. 35-37.

Andreásson S, Lindström U, Armelius B- $\AA$, Larsson $\mathrm{H}$, Berglund M, Frank A, Bergman H, Rydberg U, Zingmark D \& Tengvald K (1999) ASI - en strukturerad intervjumetod för bedömning av alkohol- och narkotikarelaterade problem. CUS skrift 1999:2. Stockholm: Socialstyrelsen, Centrum för utvärdering av socialt arbete.

Aronsson, K. (2001) "Berättande och sanning". I K. Aronsson (red.) Haverier $i$ social barnavaird. En fallstudie. Centrum för utvärdering av socialt arbete. Stockholm: Gothia.

Bergmark, Å. (1991) Socialbidrag och försörjning. Stockholm: Socialhögskolan, Stockholms universitet.

Bergmark, Å. (2002) „Ställda utanför? Mönster för långvarigt socialbidragstagande under 1990taletu. I Fattigdomi välfärdsstaten. Forskningsrådet för arbetsliv och socialvetenskap (FAS). Stockholm: Alfa Print.

Bernler G, Bjerkman A, Bäck-Wiklund M, Johnsson L \& Olsson S (1989) Vägar till och från klientskapet. Forskningsprogram för en forskargrupp vid institutionen för socialt arbete, Göteborgs universitet. Göteborg: Institutionen för socialt arbete, Göteborgs universitet.

Bernler, G. \& Bjerkman, A. (1990) Den sociala biografin. Göteborg: Daidalos.

Bernler, G. \& Johnsson, L. (1993) Den sociala journalen I: En studie i akter - deras struktur och funktion. Rapport 1993:7. Göteborg: Institutionen för socialt arbete, Göteborgs universitet.

Bernler, G. \& Johnsson, L. (1995) Den sociala Journalen II: Tre bilder av socialtjänstens klienter. Rapport 1995:7. Göteborg: Institutionen för socialt arbete, Göteborgs universitet.

Billquist, L. (1999) Rummet, mötet och ritualerna. En studie av socialbyrån, klientarbetet och klientskapet. Skriftserien 1999:4. Göteborg: Institutionen för socialt arbete, Göteborgs universitet.

Billquist, L. \& Johnsson, L. (2004) Inte längre klient? En studie av avslutade ärenden vid en barn- och familjeenhet inom socialtjänsten. Skriftserien 2004:2. Göteborg: Institutionen för socialt arbete, Göteborgs universitet.

Bryman, A. (2004) Social Research Methods. Oxford: Oxford University Press.

Bucht, S-I. (1997) Frivilliga omhändertaganden av barn. Rapport nr 40. Umeå: Institutionen för socialt arbete, Umeå universitet.

Buhr P, Ludwig M \& Priester T (1990) Die Bremer 10\%-stichprobe von sozialhilfeakten. ZeSArbetspapier Nr 1/90. Bremen: Zentrum für Sozialpolitik, Universität Bremen.

Cedersund, E. (1992) Talk, text and institutional order. A study of communication in social welfare bureaucracies. Linköping: Communication Studies, Linköping University.

Engström, C. \& Armelius, B-Å. (2005) „Implementering av en strukturerad intervju (ASI) i missbruksvård och kriminalvård». Socialvetenskaplig Tidskrift, vol 12, nr 5, s. 27-42.

Framme, G. (1997) Lättskötta och följsamma. Tidsbilder av ett sjukhem och dess patienter. Umeå: Borea.

Friis, E. (2003) Sociala utredningar om barn. En rättssociologisk studie av lagstiftningens krav, utredningarnas argumentationer och konsekvenser för den enskilde. Lund: Sociologiska institutionen, Lunds universitet.

Gelman, S. B. (1992) „Risk Management through Client Access to Case Records". Social Work, Vol. 37, s. 73-79.

Gerdner, A. (2004) „Utfall av LVM-vård - översikt och syntes av hittillsvarande studier". SoU 2004:3. Forskningsrapporter. Bilagedel till LVM-utredningens betänkande Tvång och för- 
ändring. Stockholm: Fritzes förlag.

Gustafsson, B. \& Voges, W. (1997) „Hur länge får man socialbidrag? En jämförelse mellan Sverige och Tyskland«. I 11 röster om socialbidrag - En antologi. SoS-rapport 1997:5. Stockholm: Socialstyrelsen.

Holbrook, T. L. (1995) „Finding Subjugated Knowledge: Personal Document Research". Social Work 40 (6), s. 746-751.

Hollander, A. (1985) Omhändertagande av barn. En studie av barnavårdsmål vid förvaltningsdomstolarna åren 1974, 1977 och 1982. Stockholm: Aktuell Juridik förlag.

Humlesjö, E. (1997) Barnen och socialtjänsten. 58 barns kontakt med socialtjänsten. FoU-rapport 1997:11. Stockholm: Resursförvaltningen för skola och socialtjänsten, FoU-enheten.

Hydén, L-C. (1991) Barnavårdsutredningen som identitet. FoU-rapport 1991:6. Stockholm: Stockholms socialförvaltning.

Hydén, L-C. (1995) „Det sociala misslyckandet som berättelse. Att återställa den moraliska ordningen". Socialvetenskaplig tidskrift Vol 2, nr 3, s. 194-207.

Johansson S, Bergmark A \& Lundström T (2006) Tonåringar som inte kan bo hemma. En utvärdering av jourhemspoolen i nordvästra Stockholm. Rapport 2006:2. Stockholm: CKP.

Johansson, S. (2004) Implementering av BBIC $i$ socialtjänstens organisationer - En studie av den lokala organiseringen av projektet Barns behov i centrum. Stockholm: Socialstyrelsen.

Johnsson, L. (1999) „Dokumentation och journalföring". I G Bernler, L Cajvert, L Johnsson \& H Lindgren Psykosocialt arbete. Idéer och metoder. Stockholm: Natur och Kultur.

Linderot, S. (2006) Att placera eller inte placera $i$ släktinghem, det är frägan. En studie kring familjehemsplaceringar - lagstiftning, attityder och handläggning inom socialtjänsten. Meddelanden från Socialhögskolan 2006:1. Lund: Socialhögskolan, Lunds universitet.

Lipsky, M. (1980) Street-level Bureaucracy. Dilemmas of the Individual in Public Services. New York: Russel Sage Foundation.

Lundström, T, (2000) »Om kommunernas sociala barnavård«. I M. Szebehely (red.) Välfärd, vård och omsorg. Antologi från Kommittén välfärdsbokslut (SoU 2000:38). Stockholm: Socialdepartementet.

Macdonald, K. (2001) „Using documents». I N. Gilbert (red.) Researching social life. London: Sage.

Mattson, T. (1998) „Barns mening i LVU-processen". Socialvetenskaplig tidskrift Vol 5, nr 1, s. 45-57.

Mik-Meyer, N. \& Järvinen, M. (2005) »Inledning: Kvalitative metoder i et interaktionistisk perspektivu. I M. Järvinen \& N. Mik-Meyer (red.) Kvalitative metoder $i$ ett interaktionsistisk perspektiv. Interview, observationer og dokumenter. København: Hans Reizels Forlag.

Mik-Meyer, N. (2005) „Dokumenter i en interaktionistisk begrebsramme». I M. Järvinen \& N. Mik-Meyer (red.) Kvalitative metoder i ett interaktionsistisk perspektiv. Interview, observationer og dokumenter. København: Hans Reizels Forlag.

Milton, P. \& Bergström, R. (1998) Uppsalamodellen och socialbidragstagarna. En effektutvärdering. CUS-skrift 1998:1. Stockholm: Socialstyrelsen.

Milton, P. (2000)»När man vill veta hur det går för klienterna. Att använda akter i utvärdering av socialbidragets effekter». Socialvetenskaplig Tidskrift, vol 7, nr 4, s. 361-375.

Neij, M-P. (2005) God vård och fostran - en resultatvärdering av ungdomar placerade på institution på grund av beteendeproblem. Magisteruppsats. Göteborg: Förvaltningshögskolan, Göteborgs universitet.

Nilsson, G. (1989) Fattigliv. Meddelanden från Socialhögskolan 1989:1. Lund: Socialhögskolan.

Parton N, Thorpe D \& Wattman C (1997) Child Protection. Risk and the Moral Order. Houndsmills, Basingstoke, Hampshire and London: Macmillan Press LTD.

Prior, L. (2003) Using Documents in Social Research. London: Sage.

Regnér, M. (2006) Familjebilder. Om klientfamiljer, kontaktfamiljer och idealfamiljer. Skriftserien nr 2006:9. Göteborg: Institutionen för socialt arbete, Göteborgs universitet.

Leila Billquist \& Lisbeth Johnsson: Sociala akter som empiri. 
Salonen, T. (1993) Margins of Welfare - A study of modern functions of social assistance. Kristianstad: Hällestad Press.

Salonen, T. (1998) „Klient». I V. Denvall \& T. Jacobson (red.) Vardagsbegrepp i socialt arbete. Ideologi, teori och praktik. Stockholm: Norstedts Juridik AB.

Scott, J. (1990) A Matter of Record: documentary Sources in Social Research. Cambridge: Polity Press.

SFS (2001:453) Socialtjänstlag.

Shireman, J. F. \& Grossnickle, D. (1990) „Outcome study of protective services: comparison of interviews and records as data sources». Child Welfare, Vol 69, Issue 2, s. 167-179.

Skau, G. M. (1993) Mellan makt och hjälp. Förhällandet mellan klient och hjälpare i ett samhällsvetenskapligt perspektiv. Stockholm: Liber utbildning.

Skogens, L. (2005) "Socialsekreterares bedömningar - finns någon form av konsensus? «. Socialvetenskaplig Tidskrift vol 12, $\mathrm{nr}$ 2, s. 328-344.

Socialstyrelsen (1994) Handläggning och dokumentation inom socialtjänsten. Allmänna råd 1994:3. Stockholm: Socialstyrelsen.

Socialstyrelsen (2006) Dokumentation vid handläggning av ärenden och genomförande av insatser enligt SoL, LVU, LVM och LSS. Föreskrifter och allmänna råd SOSFS 2006:5 (S). Stockholm: Socialstyrelsen.

Staff, A. (2004) »Analys av socialnämndens utredningar inför ansökan om tvångsvård enl. LVM«. SoU 2004:3. Forskningsrapporter. Bilagedel till LVM-utredningens betänkande Tvaing och förändring. Stockholm: Fritzes förlag.

Staudt, M. (1999) »The Strengths and Limitations of Case Record Reviews in Examing Family Preservation Outcome Formulation and Treatment Planning". Journal of Child \& Family Studies,
Vol. 8 Issue 4, s. 409-424.

Sundell, K. \& Egelund, T. (2001) Barnavårdsutredningar. En kunskapsöversikt. CUS. Stockholm: Socialstyrelsen.

Sundell, K. (2002) Familjerådslag i Sverige. Socialtjänstens fortsatta insatser till barn och föräldrar. FoU-rapport 2002:3. Stockholm: Forsknings- och utvecklingsenheten, Stockholms stad.

Sundell, K. (2004) Social barnavaird - omfattning, utredningar och utfall. Paper presenterat vid socialtjänstforum - ett möte mellan forskning och socialtjänst, Göteborg april 2004.

Sundell K, Vinnerljung B, Andrée Löfholm C \& Humlesjö E (2004) Socialtjänstens barn. Hur många är de, vilka är insatserna, hur ofta aktualiseras de och vad händer dem i vuxen alder? FoU-rapport 2004:4. Stockholm: Forskningsoch utvecklingsenheten, Stockholms stad.

Thomas, A. B. (2004) Research skills for management studies. London: Routledge.

Vinnerljung, B. (1992) 235 syskon med olika uppväxtöden - en retrospektiv aktstudie. Meddelanden från Socialhögskolan 1992:5. Lund: Socialhögskolan.

Vinnerljung, B. (1996) Fosterbarn som vuxna. Lund studies in social welfare XIII. Lund: Arkiv förlag.

Vinnerljung B, Sallnäs M \& Kyhle Westermark P (2001) Sammanbrott vid tonårsplaceringar - om ungdomar i fosterhem och på institution. Stockholm: Socialstyrelsen, Centrum för utvärdering av socialt arbete.

von Greiff, N. (2006) „Missbruk bland ungdomar på särskilda ungdomshem - ADAD som verktyg för bedömning och behandling". Socialvetenskaplig Tidskrift, vol 13, nr 2, s. 146-163. 


\section{Summary}

\section{Using case records as data sources in research - difficulties and possibilities}

Social workers within the Social Services Agency document daily information about their clients and the assistance given to them. We discuss in this article - both from a study in child welfare and from research, our own and others - difficulties (but also possibilities) in using case records as data sources in research.

During the research process many difficulties appeared, as the information in the case records was very insufficient. Information important for the research project (and even for the treatment) was missing, such as information about the clients' situation, problems and resources as well as information about assistance or treatment and about what takes place from time to time.

Difficulties associated with using case records such as data sources in research include the objectivity of the information, reliability, validity, in what context the documents have been established, for whom and for what purpose - the information has not been collected to be used in research. This was very evident in the study. The information in the case records, as shown in other research, was rather a result of social workers' subjective assessment of what needed to be documented or what information was considered necessary for the organization to reach a decision. The missing information, important for both the treatment and the research, can, to some extent, be explained by the lack of mutual terminology, routines and rules about what should be documented and how.

Today, within the Social Services Agency, demands are heard for evidencebased assistance, and methods for systematic documentation have been introduced. Could systematic documentation remove the problems and difficulties which are related to using case records as data sources in research? Research indicates at least that some problems will remain. As a researcher one always has to realize that documents are social constructions made by people whose values, thoughts, assumptions and organizational affiliation have an influence on what is being documented. With this awareness, the case records could be one possible source for research. Case records which are well organized and "up-to-date" often contain important information for research; information about facts and about processes. They are also easily accessible, relatively inexpensive and this is an unobtrusive way of researching. 